\title{
ANALISIS PENGARUH PENGGUNAAN MODEL PROBLEM BASED LEARNING TERHADAP MOTIVASI BELAJAR PESERTA DIDIK DI SEKOLAH DASAR
}

\author{
Acep Roni Hamdani ${ }^{1}$, Taufiqulloh Dahlan², Rina Indriani ${ }^{3}$, Ayu Ansor Karimah ${ }^{4}$ \\ 1,2,3,4 Universitas Pasundan \\ 1taufiqulloh@unpas.ac.id, 2ayuansorrka@gmail.com
}

\begin{abstract}
The background of this research is because of the low learning motivation of students. The causes of the low learning motivation of students are the lack of interest in learning, not being diligent in facing assignments, quickly giving up when faced with difficulties. Some of the causes of these problems include because the learning process is still using conventional learning. Therefore, it is necessary to innovate learning models that are in line with current needs and realities. One of the learning models that can be applied is the Problem Based Learning model. This study aims to determine: 1) To find out the concept of the Problem Based Learning model. 2) To find out the condition of students' learning motivation so far based on previous research, 3) To find out the use of Problem Based Learning models has an effect on students' learning motivation. This study uses a qualitative approach with the type of research used is library research. Sources of data obtained from books, journals, articles and publications by collecting several previous studies on the Problem Based Learning model on students' learning motivation. Based on research journals that researchers analyzed, it showed that the Problem Based Learning model had an effect on the learning motivation of elementary school students, judging by the results of students' learning tests in elementary school students' learning motivation had increased. Student learning through the Problem Based Learning model shows an influence, seen from the class that was treated using the Problem Based Learning model, the value was higher than the class that was treated with the conventional model.
\end{abstract}

Keywords: Problem Based Learning model and Learning Motivation

\section{ABSTRAK}

Penelitian ini dilatar belakangi karena motivasi belajar peserta didik yang rendah. Penyebab rendahnya motivasi belajar peserta didik yaitu tidak adanya minat untuk belajar, tidak tekun menghadapi tugas, cepat putus asa saat menghadapi kesulitan. Beberapa penyebab dari masalah tersebut di antaranya karena proses pembelajaran masih menggunakan pembelajaran konvensional. Oleh karena itu, perlu dilakukan inovasi model pembelajaran yang selaras dengan kebutuhan dan kenyataan yang terjadi sekarang. Salah satu model pembelajaran yang dapat diterapkan ialah model Problem Based Learning. Penelitian ini bertujuan untuk mengetahui: 1) Untuk mengetahui konsep model Problem Based Learning .2) Untuk mengetahui kondisi motivasi belajar peserta didik selama ini berdasarkan penelitian terdahulu, 3) Untuk mengetahui penggunaan model Problem Based Learning berpengaruh terhadap motivasi belajar peserta didik. Penelitian ini menggunakan pendekatan kulitatif dengan jenis penelitian yang dipakai adalah studi kepustakaan ( librarary research ). Sumber data yang dipeproleh dari buku, 
jurnal-jurnal ,artikel dan publikasi dengan mengumpulkan beberapa penelitian terdahulu tentang model Problem Based Learning terhadap motivasi belajar peserta didik. Berdasarkan jurnal- jurnal penelitian yang peneliti analisis, menunjukan bahwa model Problem Based Learning berpengaruh terhadap motivasi belajar peserta didik sekolah dasar, dilihat dari hasil tes belajar peserta didik dalam motivasi belajar peserta didik SD mengalami peningkatan. Belajar peserta didik melalui model Problem Based Learning menunjukkan adanya pengaruh, dilihat dari kelas yang diberi perlakuan dengan menggunakan model Problem Based Learnin nilainya lebih tinggi dibandingkan kelas yang diberi perlakuan model konvensional.

Kata Kunci: model Problem Based Learning dan Motivasi Belajar

\section{A. Pendahuluan}

Belajar merupakan kegiatan pokok dalam proses pembelajaran di sekolah. Kegiatan belajar mengajar dalam rangka mewujudkan tujuan pendidikan sangat di pengaruhi oleh beberapa faktor baik itu faktor luar maupun faktor dalam antara lain faktor dari luar peserta didik adalah lingkungan tempat belajar, kurikulum, program/bahan belajar, sarana dan fasilitas, guru .Sedangkan faktor dari dalam diri peserta didik adalah minat, bakat dan salah satunya motivasi.

$\begin{array}{lcr}\text { Motivasi } & \text { belajar } & \text { sangat } \\ \text { dibutuhkan } & \text { dalam } & \text { proses } \\ \text { pembelajaran } & \text { agar peserta didik } \\ \text { bersemangat } & \text { dalam belajar. }\end{array}$

Pembelajaran yang di lakukan oleh peserta didik akan lebih maksimal apabila peserta didik mempunyai motivasi yang tinggi. Menurut (Sardiman A.M, 2016 hlm 75) berpendapat bahwa motivasi belajar adalah keseluruhan daya penggerak dalam diri peserta didik yang menimbulkan kegiatan belajar ,yang menjamin kelangsungan dari kegiatan belajar dan memberikan arah kegiatan belajar sehingga tujuan yang dikehendaki oleh subyek belajar itu dapat tercapai.

Motivasi belajar yang ideal dalam rangka pencapaian perkembangan diri peserta didik menurut (Sardiman A.M., 2011, hlm 83) yaitu : tekun dalam mengerjakan tugas, dapat bekerja terus menerus dalam waktu yang lama, tidak pernah berhenti sebelum selesai, ulet menghadapi kesulitan (tidak lekas putus asa) , tidak memerlukan dorongan dari luar untuk berprestasi sebaik mungkin (tidak cepat puas dengan prestasi yang telah dicapainya), menunjukkan minat terhadap bermacam-macam masalah, lebih senang bekerja mandiri, cepat bosan pada tugas yang slalu di 
berikan / rutin, dapat mempertahankan pendapatnya yang ia sampaikan, tidak mudah melepaskan hal yang diyakini, senang mencari tahu dan memecahkan masalah saat di berikan soal.

\section{Pada kenyataanya masih} banyak peserta didik yang kurang termotivasi saat pembelajaran berlangsung. Penelitian lakukan oleh (Yanti et al., 2017. hlm 16 ) peserta didik tidak tekun dalam mengerjakan tugas akibatnya peserta didik kurang merespon saat guru bertanya lalu peserta didik Menyelesaikan keseluruhan suasana dalam belajar menyebabkan peserta didik kurang memiliki pengetahuan tentang belajar dan masih ada beberapa peserta didik yang masih jarang membantu teman dalam mengerjakan tugas yang diberikan, ada yang merasa canggung atau tidak pasti saat belajar bersama teman. Ada pesertadiidk yang berani memberikan pandangan dan ada juga yang tidak terlibat, selain itu masih banyak peserta didik yang tidak mencatat atau menyimpulkan materi dengan asumsi tidak ada pemberitahuan dari instruktur. Pengalaman yang kurang ketika pembelajaran dilatarbelakangi oleh sistem pembelajaran yang tidak menarik pertimbangan peserta didik atas kemauannya sendiri ketika pembelajaran menyebabkan ketiadaan energi dalam setelah ilustrasi. Sistem pembelajaran diselesaikan dengan menggunakan strategi biasa/alamat dimana dalam prosesnya pendidik menyampaikan materi yang kemudian dilanjutkan dengan pemberian tugas kepada peserta didik baik secara sendirisendiri maupun secara berkelompok.

Berdasarkan hasil dari beberapa masalah penelitian yang telah di paparkan di atas, dapat di tarik kesimpulkan bahwa peserta didik kurang termotivasi dalam belajar di tandai dengan sebagian peserta didik kurang aktif / pasif saat pembelajaran berlangsung, kurangnya respons dari peserta didik saat guru bertanya, beberapa peserta didik yang kurang percaya diri saat mengemukakan pendapat yang menjadikan motivasi belajar peserta didik rendah ,peserta didik jarang melakukan dinamika kelompok dalam pembelajaran mengakibatkan peserta didik kurang termotivasi dalam pembelajaran ,peserta didik cenderung melakukan aktivitas lain saat guru menjelaskan materi, kurangnya minat belajar peserta didik cenderung tidak 
memiliki motivasi untuk belajar. dan guru masih menggunakan model pembelajaran konvensional dalam menyampaikan materi kepada peserta didik

Beberapa penyebab yang menyebabkan masalah - masalah tersebut di antaranya karena proses pembelajatan selama ini strategi ceramah dengan tujuan agar peserta didik bersifat laten dan hanya fokus dan memperhatikan klarifikasi sedangkan guru mengolah data di kelas atau pembelajaran kelas dan bersifat Teacher Centered atau belajat terjadi satu arah .

Dengan asumsi latihan pembelajaran benar-benar menggunakan metode pembelajaran lama, maka akan sulit bagi pengajar dan peserta didik untuk menyelesaikan kondisi ini. Dengan cara ini, penting untuk memajukan model pembelajaran yang sesuai dengan kebutuhan saat ini dan faktor nyata. Salah satu model pembelajaran yang dapat diterapkan adalah model Problem Based Learning (PBL). Model Pembelajaran Berbasis Masalah yang mendorong peserta didik untuk mengembangkan wawasannya sendiri dan pendidik memberikan pintu terbuka yang luas kepada peserta didik untuk menemukan dan melacak jawaban pilihan untuk masalah itu sendiri. Jadi peserta didik dapat memperluas inspirasi belajar mereka dengan menemukan respons aktual dengan menggunakan masalah dan menyelidiki wawasan mereka tanpa diberikan standar yang mengharapkan peserta didik untuk melalui proses pelacakan data yang terus terjadi hal yang sama antara peserta didik yang satu dan yang lainnya. Peserta didik dapat menyelidiki wawasan mereka tanpa diberikan standar yang mengharapkan peserta didik untuk melalui cara yang paling umum untuk melacak data yang terus berjalan sesuatu yang serupa antara satu peserta didik dan lainnya.

Hal ini sejalah dengan pendapat (Harapit, 2018) Problem Based Learning merupakan model pembelajaran yang menghadapi pesertadidik dengan suatu masalah sehingga peserta didik dapat menumbuhkan kemampuan penalaran dan berpikir kritis yang lebih tinggi. Menurut (Surya, 2017) Model Problem Based Learning adalah suatu model pembelajaran yang dikaitkan dengan masalah yang ada di 
dunia nyata sebagai langkah awal terhadap peserta didik saat belajar untuk mendapatkan informasi atau pengetahuan dan pokok konsep dari pembelajaran yang dimiliki oleh peserta didik sebelumnya dan terbentuklah pembelajaran yang baru bagi peserta didik.

\section{Berdasarkan}

beberapa penelitian terdahulu di atas, peneliti menarik kesimpulkan bahwa rendahannya motivasi belajar peserta didik karena guru masih menggunakan model pembelajaran konvensial dan guru kurang mengaitkan pembelajaran dengan dunia nyata peserta didik Selanjutnya, penting untuk memajukan model pembelajaran yang sesuai dengan kebutuhan saat ini dan faktor nyata. Dengan menerapkan model Problem Based Learning dalam pembelajaran dapat meningkatkan motivasi belajat peserta didik dan mendukung siswa untuk membangun wawasan mereka sendiri dan instruktur memberikan pintu terbuka yang luas kepada siswa untuk menemukan dan melacak jawaban pilihan untuk masalah itu sendiri.

Dengan melihat isu-isu terkini dan beberapa pengaturan yang sangat menguatkan, peneliti tertarik untuk

menggunakn

model

ProblemBased Learning, dengan kata lain model pembelajaran ini bisa menumbuhkan kemampuan berfikir dalam memecahkan masalah tentang pengetahuan yang diperoleh dari hasil diskusi bersama kelompok atau individual. Berdasarkan uraian di atas maka penulis mengangkat judul "Analisis Pengaruh Penggunaan Model Problem Based Learning Terhadap Motivasi Belajar Peserta Didik di Sekolah Dasar “

\section{B. Metode Penelitian}

Penelitian ini menggunakan penelitian studi kepustakaan (Library Research). Jenis metode penelitian ini digunakan untuk membahas tentang penggunaan model Problem Based Learning terhadap motivasi belajar peserta didik. Studi kepustakaan (Library Research) merupakan suatu studi yang dipergunakan dalam mengumpulkan data serta informasi dengan bantuan berbagai macam material yang terdapat di perpustakaan seperti dokumen, buku, majalah, kisah-kisah sejarah, dsb.

Pendekatan

yang dipergunakan pada penelitian ini ialah pendekatan kualitatif. Penelitian kualitatif artinya metode penelitian umum, sebab dapat berubah dan 
berkembang tergantung pada situasi di lapangan. Menurut Sukmadinata dalam penelitian kualitatif yang bertujuan untuk mendeskripsikan dan menganalisis realitas, peristiwa, aktivitas sosial, perilaku, agama, persepsi dan pemikiran individu secara individu maupun kolektif.

\section{C.Hasil Penelitian dan Pembahasan}

Arends di dalam (Ariandi, 2016 hlm 1315), Problem Based Learning merupakan suatu model pembelajaran dengan cara peserta didik menghadapi masalah nyata tentang masalah yang sebenarnya, sehingga peserta didik dapat membangun wawasan mereka sendiri dan memiliki makna tersendiri, yang dapat digunakan sebagai dasar untuk melakukan latihan analisis dan penyelidikan kemudian menumbuhkan keahlian yang lebih tinggi ,menemukan sendiri dan memandirikan peserta didik.

\section{Problem Based Learning} (Trianto, 2010) yaitu suatu model pembelajaran ditinjau dari banyaknya masalah yang memerlukan penelitian nyata, yaitu penelitian yang membutuhkan solusi nyata terhadap masalah yang nyata. Pendapat tersebut sejalan dengan (Surya, 2017) Model ProblemBased Learning yaitu model yng dikaitkan dengan permasalahan yang ada di dunianyata sebagai langkah awal terhadap peserta didik saat belajar untuk mendapatkan informasi atau pengetahuan dan pokok konsep dari pembelajaran yang dimilikii oleh peserta didik sebelumnya $d n$ terbentuklah pembelajaran yang baru bagi peserta didik

Kesimpulan pengertian model ProblemBased Learning yaitu model yang membuka peserta didik pada permasalahan nyata untuk memulai belajar melatih peserta didik berpikir kritis, sistematis, analitis, menambah informasi berharga dan kemampuan untuk menyelesaikan hidup mereka untuk saat ini dan nanti.dan merupakan salah satu model pembelajaran kreatif yang dapat meembantu kondisi belajar yang dinamis kepada peserta didik dan dapat membangun motivasi hasil belajar peserta didik.

Problem based learning dapat di laksanakan dengan langkahlangkah sebagai berikut menurut (H.E.Mulyasa, 2017) :

1. Mengorientasikan peserta didik pada masalah. Tahap ini di lakukan untuk memfokuskan peserta didik ( 
mengamati ) masalah yang menjadi objek pembelajaran,

2. Mengorganisasikan kegiatan pembelajaran. Mengorganisasikan pembelajaran merupakan salah satu kegiatan agar peserta didik menyampaikan berbagaikan pertanyaan (menannya) terhadap masalah yang disajikan .

3. Membimbing penyelidikin mandiri dan kelompok. Pada tahap ini peserta didik melakukan percobaan ( mencoba) untuk memperoleh data dalam rangka menjawab atau menyelesaikan masalah yang dikaji .

4. Mengembangkan dan menyajikan hasil karya. Peserta didik menghubungkan data yang ditemukan dari percobaan dengan berbagai data lain dari berbagai sumber ( mengkomunikasikan)

5. Analisis dan evaluasi proses pemecahan masalah. Setelah peserta didik mendapat jawaban terhadap masalah yang ada, selanjutnya dianilisis dan dievaluasi ( menalar).

Kesimpulan daru beberapa pendapat ahli tentang langkahlangkah model Problem Based Learning diatas, dapat urutkan langkah-langkah model Problem
Based Learning berikut ini : (1) mengorientasikan peserta didik terhadap masalah, mengorganisasikan peserta didik untuk belajar, (3) membimbing penyelidikan individual maupun kelompok, (4) mengembangkan dan menyajikan hasil karya, menganalisis dan mengavaluasi proses pemecahan masalah

Motivasi belajar di pandang sebagai suatu keadaan yang terdapat pada diri individu dimana ada suatu dorongan untuk melakukan sesuatu guna mencapai tujuan . Menurut (Sardiman A.M, 2016) berpendapat motivasi belajar ialah daya dorong utama umum pada peserta didik yang meningkatkan kegiatan pembelajaran, yang mengalami keselarasan dari aktivitas pembelajaran dan memberikan bimbingan dari kegiatan pembelajaran akibatnya tujuan yang diinginkan oleh peserta didik dapat tercapai.

Mc Donald dalam dalam (Sardiman A.M, 2018) motivasi ialah penyesuaian energi dalam seorang individu yang digambarkan dengan timbulnya perasaan dan reaksi untuk mencapai suatu tujuan dengan demikian munculnya motivasi ditandai 
dengan adanya perubahan prilaku dalam diri seseorang yang mampu mengerti atau tidak. Pendapat tersebut sejalan dengan (Hamzah B Uno, 2017) hakikat motivasi belajar adalah dorongan dari luar dan dalam di pada peserta didik yang sedang belajar untuk membuat perubahan prilaku, sebagaian besar dengan indikator atau komponen yang menunjang.

Berdasarkan pemaparan para ahli diatas dapat disimpulkan bahwa motivasi belajar merupakan keinginan yang muncul dalam diri setiap orang mengadakan perubahan tingkah laku menjadi bersemangat untuk melakukan atau tidak melakukan suatu gerakan untuk mencapai tujuan yang ideal. Selain itu, motivasi juga di pengaruhi oleh faktor luar seperti lingkungan

upaya untuk meningkatkan motivasi belajar yakni guru harus dapat menjadikan pembelajaran lebih menarik serta inovatif agar peserta didik baik belajar secara individual di dalam kelas secara optimal maupun dengan pembelajaran praktis. Tidak cukup menyajikan konten di setiap pelajaran untuk membuat tugas yang membosankan, dibutuhkan inovasi yang lebih kreatif untuk mendapatkan lebih banyak perhatian yaitu dengan mengembangkan

model pembelajaran dan salah satu model pembelajaran yang cocok yaitu model problem based learning

Belajar menggunakan model problem based learning tentunya mempunyai pengaruh terhadap motivasi belajar peserta didik. Hasil penelitian yang telah berhasil dikumpulkan dalam penelitian ini perlu dijabarkan satu-persatu, agar terlihat detail dalam peningkatan variabel dampak dan akibat dengan mengimplementasikan model problem based learning . Berikut akan dipaparkan beberapa jurnal pengaruh model problem based learning terhadap motivasi belajar peserta didik .

Berdasarkan penelitian yang dilakukanoleh (Siti Nurjanah, 2021) yang menyatakan bahwa bahwa penerapan model ProblemBased Learning memiliki pengaruh terhadap motivasi belajar peserta didik dengan mata pelajaran IPS terpadu hasil penelitian yang diperoleh saat uji hipotesis yang mendapatkan perolehan nilai sig. 2 tailed 0,000 , dimana 0,000 tersebut $<0,05$. dimana peserta didik saat menggunakan model tersebut menjadikan peserta 
didik menjadi lebih aktif dalam kegiatan pembelajaran dan saat pembelajaran adanya motivasi belajar peserta didik menjadikan tidak bosan saat belajar.

Penelitian yang dilakukan (I Gusti Ketut Yasmini, 2021) Dapat disimpulkan bahwa pemanfaatan model pembelajaran PBL dapat memperluas motivasi belajar IPA siswa kelas IV Semester I di SDN 3 Banyuasri Kecamatan Buleleng Kabupaten Buleleng Tahun Pelajaran 2020/2021. Penerapan dari penerapan model pembelajaran problem-based learning ini adalah mendorong peserta didik untuk berpikir inovatif, inventif, menyajikan pemikiran baru, dan mendorong peserta didik untuk memperoleh sikap percya diri.

Penelitian yang dilakukan (Tomas, 2020) Berdasarkan hasil pencarian dapat dianalisis bahwa motivasi belajar peserta didik pada pembelajaran aritmatika bilangan dengan menggunakan model pembelajaran PBL lebih tinggi daripada pembelajaran menggunakan model pembelajaran tradisional. Pada penerapan model PBL mengalami peningkatan sebesar 19.67. Nilai ini dilihat dari selisih antara nilai pretes yaitu 37,33 dan nilai postes yaitu 57,00 . Ada pengaruh motivasi belajar antara peserta didik yang diperlihatkan pembelajaran PBL, ada peningkatan motivasi belajar peserta didik karena pemanfaatan pembelajaran PBL belajar matematika peserta didik kelas 4 SD.

Penelitian yang dilakukan (Arief \& Sudin, 2016) Peserta didik menunjukkan respon positif terhadap pembelajaran matematika dengan menggunakan pendekatan problembased learning . Motivasi belajar peserta didik berkembang secara signifikan melalui pembeljaran dengan menggunakan

pendekatan pembelajaran problem based learning .bantuan yang diberikan dari pembelajaran dengan pendekatan $P B L$ terhadap peningkatan motivasi belajar peserta didik yaitu 2,02\%. Pembelajaran matematika dengan menggunakan

pendekatan pembelajaran berbasis masalah pada dasarnya lebih baik dibandingkan dengan pembelajaran matematika yang menggunakan metode biasa dalam memperluas motivasi belajar peserta didik pada materi dekat di kelas $\mathrm{V}$.

Penelitian yang dilakukan (Sulamiasih. Ni Kadek, Nyoman 
Dantes \& Program, 2015) Akibat dari analisis deskriptiif diarahkan pada motivasi belajar, bahwa model $P B L$ mempengaruhi motivasi belajar dan prestasi belajar IPA peserta didik kelas VI. Menunjukkan bahwa nilai rata-rata motivasi belajar IPA peserta didik dengan pembelajaran berbasis masalah adalah 124,18 dan rata-rata skor motivasi belajar matematika dengan pembelajaran konvensional adalah 99,69. Terdapat perbedaan motivasi belajar yang sangat besar dalam pembelajaran matematika peserta didik kelas 6 SD Gugus II Kecamatan Tejakula yang menyukai pembelajaran problem based learning dengan peserta didik yang mengikuti pembelajaran konvensional (teacher center ).

Penelitia yang di lakukan oleh (Pradnyana, P.B., Marhaeni, A.A.I.N., Candiasa, 2013) dikatakan model pembelajaran Problem Based Learning berpengaruh terhadap motivasi belajar IPA Pada penerapan model PBL mengalami peningkatan sebesar 34,71 Nilai ini dilihat dari selisih antara nilai pretes yaitu 89,29 dan nilai postes yaitu 124 . Hal ini dapat disimpulkan bahwa terdapat perbedaan motivasi belajar IPA antara peserta didik yang mengikuti model Problem Based Learning dan peserta didik yang mengikuti model pembelajaran biasa.

Penelitian yang dilakukan oleh (San, 2016) Hasil review ini menunjukkan bahwa model pembelajaran PBL dan dampak motivasi belajar terhadap hasil belajar IPA peserta didik berbeda dengan model pembelajaran langsung. pelaksanaan PBL dengan fokus pada motivasi belajar memberikan kontribusi yang baik untuk mendukung latihan pembelajaran IPA di sekolah Dalam pemanfaatan model PBL terdapat perluasan motivasi belajar dengan 14,95 Nilai ini dilihat dari selisih antara nilai pretest yaitu 66,65 dan nilai postes yaitu 81,60

\section{E. Kesimpulan}

Pemilihan model yang cocok dengan pembelajaran akan membuat pengaruh besar terhadap motivasi belajar peserta didik, karena model pembelajaran jika dilaksanakan oleh guru dengan sesuai maka pembelajaran akan berlangsung secara efektif. Pengaruh model problem based learning terhadap motivasi belajar peserta didik saat belajar, diukur dengan hasil belajar peserta didik yang telah menjalani 
jenjang pendidikan tertentu. Guru yang masih menggunakan pembelajaran konvensional, sehingga peserta didik berada di kelas merasa bosan dan di dominasi oleh guru . Sebagian besar peserta didik yang tidak aktif dalam pembelajaran mereka biasanya akan duduk, mencatat dan memperhatikan apa yang dikatakan guru dan hanya beberapa mengajukan pertanyaan. Perlu model pembelajaraan imajinatif yang dapat menjiwai peserta didik untuk berperan serta secara efektif saat belajar sehingga mendapatkan hasil yang baik, dengan menerapkan model pembelajaran Problem Based Learning (PBL) yang dapat meningkatkan motivasi belajar peserta didik. Hasil tersebut menunjukan bahwa model Problem Based Learning berpengaruh terhadap motivasi belajar peserta diidik

\section{DAFTAR PUSTAKA}

Ariandi, Y. (2016). Analisis

Kemampuan Pemecahan

Masalah Berdasarkan Aktivitas

Belajar pada Model

Pembelajaran PBL. PRISMA,

Prosiding Seminar Nasional

Matematika, X(1996), 579-585.

https://journal.unnes.ac.id/sju/ind ex.php/prisma/article/view/21561

Arief, H. S., \& Sudin, A. (2016).

Meningkatkan Motivasi Belajar

Melalui Pendekatan Problem-

Based Learning (Pbl).

Meningkatkan Motivasi Belajar

Melalui Pendekatan Problem-

Based Learning (Pbl), 1(1), 141150.

https://doi.org/10.23819/pi.v1i1.2

945

H.E.Mulyasa. (2017). Guru dalam

Implementasi Kurikulum 2013.

Remaja Rosdakarya.

Hamzah B Uno. (2017). Teori

Motivasi dan Pengukurannya -

Google Books. Jakarta : Bumi

Aksara.

https://www.google.co.id/books/e dition/Teori_Motivasi_dan_Peng ukurannya/v_crEAAAQBAJ?hl=i $d \& g b p v=1$

Harapit, S. (2018). Peranan problem based learning (pbl) terhadap kemampuan pemecahan masalah dan motivasi belajar peserta didik. Jurnal Pendidikan Tambusai|, 2, 912-917.

I Gusti Ketut Yasmini. (2021).

Penerapan Model Pembelajaran Problem Based Learning untuk Meningkatkan Motivasi dan Hasil Belajar Biologi Siswa. Justek: 
Jurnal Sains Dan Teknologi,

5(1), 22.

https://doi.org/10.31764/justek.v2

i1.3710

Pradnyana, P.B., Marhaeni, A.A.I.N.,

Candiasa, I. M. (2013).

PENGARUH PEMBELAJARAN

BERBASIS MASALAH

TERHADAP MOTIVASI

BELAJAR DAN PRESTASI

BELAJAR MATEMATIKA SISWA

KELAS IV SD. E-Journal

Program Pascasarjana

Universitas Pendidikan Ganesha

Jurusan, 3.

San, S. (2016). PENGARUH MODEL

PEMBELAJARAN PROBLEM

BASED LEARNING DAN

MOTIVASI BELAJAR

TERHADAP HASIL BELAJAR

SAINS SISWA SD. Annual

Proceeding, 2016(4), 50-64.

Sardiman A.M. (2011). Interaksi dan

Motivasi Belajar Mengajar. PT

Rajagrafindo.

Sardiman A.M. (2016). Interaksi dan

Motivasi Belajar Mengajar. PT

Raja Grafindo.

Sardiman A.M. (2018). Interksi \&

Motivasi Belajar Mengajar. PT

Raja Grafindo.

Siti Nurjanah, R. D. A. (2021).

PENGARUH MODEL
PEMBELAJARAN PROBLEM

BASED LEARNING (PBL)

TERHADAP MOTIVASI

BELAJAR IPS TERPADU PADA

MATERI KEGIATAN EKONOMI.

JIIPSI: Jurnal IImiah IImu

Pengetahuan Sosial Indonesia,

1(1), 13-23.

Sulamiasih. Ni Kadek, Nyoman

Dantes, I. M. C., \& Program.

(2015). PENGARUH

PEMBELAJARAN BERBASIS

MASALAH TERHADAP SISWA

KELAS VI SD GUGUS II

KECAMATAN TEJAKULA. E-

Journal Program Pascasarjana

Universitas Pendidikan Ganesha,

5, 1-7.

Surya, Y. F. (2017). Penerapan

Model Pembelajaran Problem

Based Learning untuk

Meningkatkan Hasil Belajar

Matematika Siswa Kelas IV SDN

016 Langgini Kabupaten

Kampar. Jurnal Pendidikan

Matematika, 1(1), 38-53.

https://bit.ly/2MXn3xs

Tomas, T. P. (2020). PENGARUH

PENGGUNAAN MODEL

PROBLEM BASED LEARNING (

PBL ) TERHADAP MOTIVASI

BELAJAR MATEMATIKA PADA

SISWA KELAS 4 SD. Jurnal 
Pendidikan Dan Pengajaran

Guru Sekolah Dasar

(JPPGuseda), 03, 13-18.

Trianto. (2010). Model Pembelajaran

Inovatif-Progresif Konsep,

Landasan, dan Implementasi

Pada Kurikulum Tingkat Satuan

Pendidikan (KTSP). Kencana. 